\title{
The Effect of Agricultural and Industrial Activities on the Groundwater Quality at the North-Eastern Part of El-Fayoum Depression, With the Possibility of Heavy Metals Removals Using Some Clay Minerals
}

\author{
Reda G. M. Ibrahim and Mohamed E. A. Ali
}

Hydrogeochemistry Department., Desert Research Center, Cairo 11753, Egypt.

\author{
Received: 05 May $2020 \quad$ Accepted: 20 June $2020 \quad$ Published: 30 July 2020
}

\begin{abstract}
The aim of the current research is to study the possible effects of the agricultural and industrial activities on the composition of groundwater at Northeast of El Fayoum depression, Egypt using the conventional geochemical tools and the modern multivariate statistical analyses. The groundwater is extracted from the Quaternary aquifer which is composed of sand and high content of clay with lateral and vertical changes in lithology. The salinity of canals water range from 256 to $299 \mathrm{ppm}$ indicating fresh water category, while the salinity of drains water vary between $1370 \mathrm{ppm}$ and $4009 \mathrm{ppm}$ reflecting brackish water category because drains continuously receive soluble salts from land washing and excess irrigation water. The salinity of the Quaternary groundwater ranges from $574 \mathrm{ppm}$ to $8953 \mathrm{ppm}$ indicating fresh to brackish water with only two saline samples (Nos. 24 and 26) located east of Sinores City. The high salinity of these water samples may be due to the over-pumping and/or closeness to Lake Qarun. The most dominant water type $(\mathrm{Cl}-\mathrm{Na})$ is represented by $44 \%$ of groundwater samples followed by $\mathrm{HCO}_{3}-\mathrm{Na}(28 \%)$ and $\mathrm{SO}_{4}-\mathrm{Na}$ water types. There is no pollution with some heavy metals $(\mathrm{Ag}, \mathrm{Cd}$, $\mathrm{Cr}, \mathrm{Mn}, \mathrm{Mo}, \mathrm{Ni}, \mathrm{Zn}$ ) because their concentrations are less than the maximum permissible limits. Most surface and groundwater systems are polluted with iron. Water of most canals is not polluted with lead $(\mathrm{Pb})$, while groundwater and half of drains are polluted with $\mathrm{Pb}$. Utilizing kaolinite clay has a great deal of promise for removing copper (II) ions from real wastewater samples. The intensive agricultural and industrial activities have clear effect on surface and groundwater quality due to the application of fertilizers containing $\mathrm{P}$ and $\mathrm{N}$ as well as industrial effluents. The multivariate statistical analyses (including correlation and cluster analyses) show that the hydrogeochemical processes affecting groundwater composition are found to be sulfate dissolution, ion exchange and water-rock interactions.
\end{abstract}

Keywords: Agricultural activities, heavy metals, pollution, statistical analyses, Northeast El Fayoum, Egypt

\section{Introduction}

El Fayoum depression is one of the most important agriculture lands of Egypt due to its good soil cover and the high crop productivity (El Abd and El Osta, 2014). In this depression which located in the Western Desert of Egypt, water-logging problem is stated to be serious in the areas lying in the lower reaches of El Fayoum area (El sheikh 2004). Hoffman and Durnford 2000 reported how soil salinity and water-logging problems have developed worldwide and the speed with which they are advancing at present. The historical places as Hawwara and Lahun pyramids helped El Fayoum to be one of the most attractive and wonderful touristic places in Egypt. The depression is exposed to several problems as water-logging and soil salinization due to the human activities in the new reclaimed area located in the desert periphery of the old cultivated lands. These problems reduce the crop productivity in the old cultivated lands.

The declining (deterioration ) of water quality has become a global issue of concern as human population grows, industrial and agricultural activities expand and potential changes in climate might threaten the hydrological cycle (WWAP 2009). Bad water quality has also a direct impact on the water quantity because polluted water reduces the amount of useable water within a given area. In general, the water crisis tends to be due to a water quantity problem and/or water quality concerns (Ongley 1999 and Abdel Wahed et al., 2014). The desertification is another challenge that retards the efforts of development in El Fayoum depression as indicated from the study of El Baroudy (2013). 
The present study is a systematic attempt for rapid, reliable assessment and delineation of the surface and groundwater quality deterioration in the area Northeast El Fayoum depression. A trial is also made to give an explanation for the effect of different agricultural, industrial and touristic activities on the quality of water resources at the area under consideration and accordingly suggesting suitable solutions to minimize their harmful effects.

\section{Location and hydrometeorology}

Northeast El Fayoum area is located southwest of Cairo by about $100 \mathrm{Km}$ and northwest of Beni Suef by about $30 \mathrm{Km}$, and it is situated between latitudes $29.1^{\circ} \mathrm{N}$ and $29.7^{\circ} \mathrm{N}$ and longitudes $30.5^{\circ} \mathrm{E}$ and $31.0^{\circ} \mathrm{E}$ (Fig. 1).

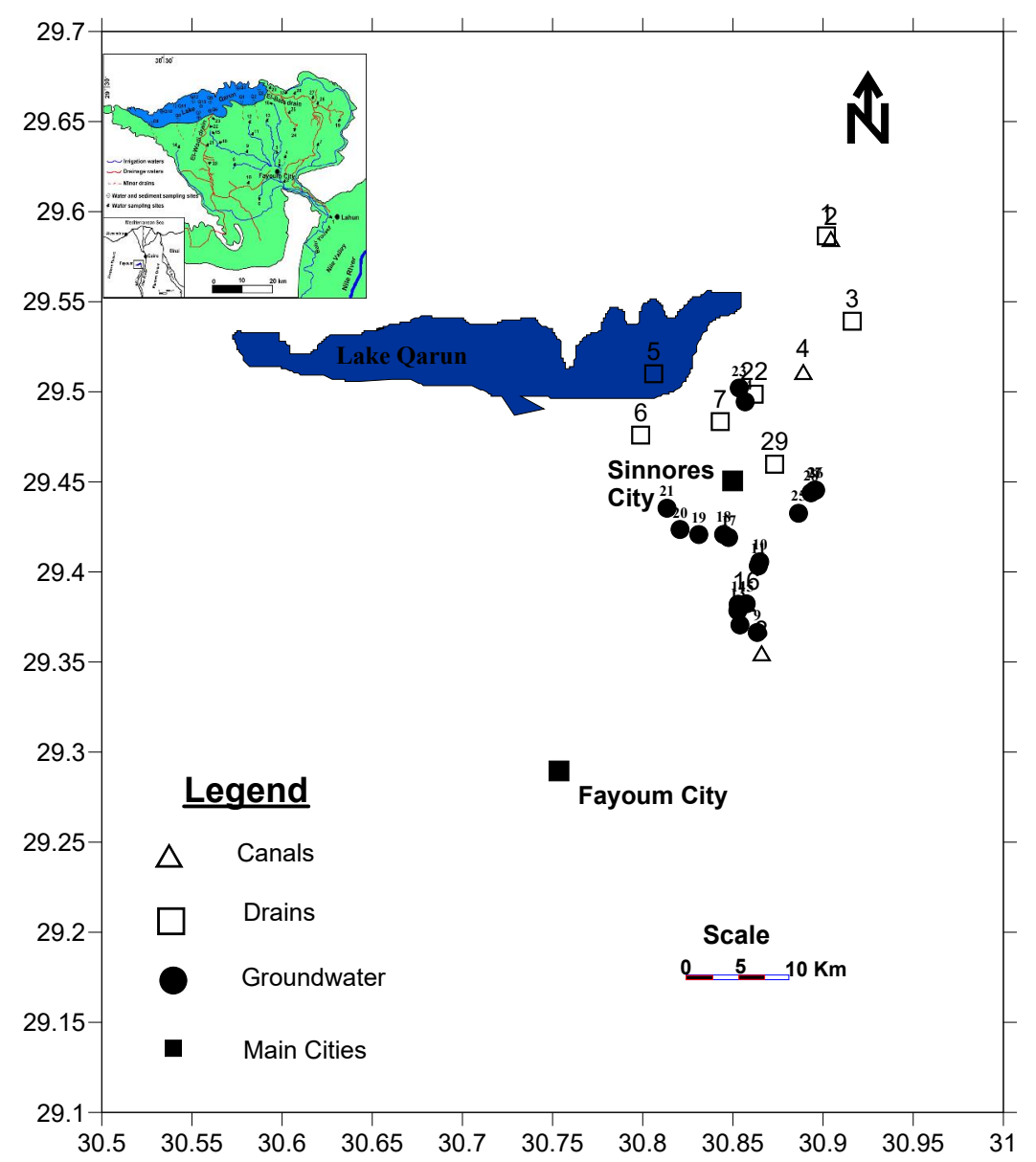

Fig. 1: Key map and samples sites of northeast El Fayoum area, Egypt

El Fayoum depression is a water distribution center for domestic demands in the province and a network of canals and small pumping stations delivers water also to the agricultural regions. Unlike most Egyptian Governorates which are conveyed directly to the Nile River, the Fayoum Governorate is unique in such as all its drainage water flows towards Lake Qarun. Nile water is the main source of irrigation in El Fayoum. Bahr Wahba bonded the study area from north and northwest and Bahr yousef and El Agooze canal from south and southwest, respectively. The main irrigation canals in El Fayoum Governorate are Bahr Hasan Wasef and Bahr Yousef, while the main drains are El bates and El Wadi drain.

The climate is characterized generally by hot, long and dry summer and warm, short winter with scarce precipitation. The average annual rainfall is around $10.3 \mathrm{~mm}$ which is relatively low (i.e., the main characters of Egypt's arid belt). The great temperature differences between summer and winter and between day and night characterizes this belt as well. The temperature ranges between $35.1^{\circ} \mathrm{C}$ and $46.7^{\circ} \mathrm{C}$ in summer months and from $20^{\circ} \mathrm{C}$ to $21.5^{\circ} \mathrm{C}$ during winter months. The total annual evaporation 
intensity reaches $2296 \mathrm{~mm} /$ year (high evaporation rate), and the annual mean of relative humidity is $51.6 \%$ (Baioumy et al., 2010).

\section{Physical setting}

The geomorphology, stratigraphy and structural geology of El Fayoum area have attracted the attention of many researchers including Beadnell (1905), Tamer (1968), Kusky et al., (2001) and E1 Abd \& El Osta, (2014).

\subsection{Geomorphology}

Geomorphologically, Tamer (1968) subdivided El Fayoum area into four geomorphic units. (1) The tableland areas bounding El Fayoum depression from east, south and west, separating it from the Nile Valley and Wadi El Rayan depression. (2) The morphotectonic depressions include El Fayoum depression (+23 to $-43 \mathrm{~m}$ ) and Wadi El Rayan depression (-60 m). (3) Lakes which include the natural lake (Qarun Lake) and artificial lakes which distinguish Wadi El Rayan depression. (4) The great monoclinal edge (Gebel Qatrani $+400 \mathrm{~m}$ ) which bounds El Fayoum depression from north and northwest.

\subsection{Geological setting}

El Fayoum area and its vicinities are occupied by sedimentary rocks belonging to Tertiary and Quaternary Eras (Fig. 2). The surface exposure has a thickness of about $848 \mathrm{~m}$ (El Sheikh, 2004).

The Tertiary deposits are differentiated into Pliocene, Miocene, Oligocene and Eocene rocks as follows: The Pliocene deposits $(90 \mathrm{~m}$ thick) are defined in the Nile-Fayoum divide forming of fossiliferous sandstone in some places overlain by the Quaternary sand and gravels (Said 1960 and 1981). The Miocene rocks (20 m thick) are exposed at Gebel Qatrani to the north of El Fayoum depression overlying basalt exposures. They are composed of a series of alternating beds of sand and gravels with silicified wood remains. The Oligocene rocks (275 m thick) are encountered underneath the Miocene rocks at Gebel Qatrani area and capped by basalt sheet. They are composed of sand and sandstone with shale and marl interbeds. These rocks are rich in silicified wood and land animals (crocodiles, tortoises and turtles). The Eocene rocks (390 m thick) have a wide distribution in El Fayoum-Wadi El Rayan area (Beadnel 1905). They are distinguished into Upper and Middle Eocene rocks. Upper Eocene rocks are formed of a series of escarpments overlooking El Fayoum depression from the eastern side. The rock succession is composed mainly of sand (69\%), shale (19\%) and limestone (12\%) with high fossil content. These facies and faunal content indicate shallow marine environment. On the other hand, Middle Eocene rocks constitute the oldest exposed rocks in El Fayoum area and its vicinities. They are represented mainly by limestone and marl with shale intercalations.

The Quaternary deposits are distinguished into: Pleistocene deposits and Holocene as follows:

The Pleistocene deposits are differentiated into old lacustrine and old Nilotic deposits. Old lacustrine deposits ( $45 \mathrm{~m}$ thick) are present within the depression area in the form of terraces at levels $+43 \mathrm{~m},+30 \mathrm{~m}$ and $+25 \mathrm{~m}$ indicating fresh water lake, feeded by the Nile during the Pleistocene times. They consist mainly of clay, fine to medium and coarse sands with considerable amounts of calcareous and gypsiferous materials. Old lacustrine deposits show high content of mica, crystalline gypsum, iron, manganese oxides, sand debris, calcareous fragments and organic and fossil remains. Old Nilotic deposits (190 m thick) are recognized at the Nile-Fayoum divide where they are differentiated into terraces at levels $+89 \mathrm{~m},+112 \mathrm{~m},+134 \mathrm{~m}$ and $+167 \mathrm{~m}$. They are composed of sand and gravels forming a good groundwater aquifer.

The Holocene deposits are distinguished into; aeolian deposits, young lacustrine deposits and young Nilotic deposits. Aeolian deposits are composed of loose quartz sand. Young lacustrine deposits are well defined in El Fayoum depression, associated with the lake development and composed of fine sand and clay with thin relics of gypsum and carbonate materials forming the agriculture soil. Young Nilotic deposits have a variable thickness $(1 \mathrm{~m}$ to $12 \mathrm{~m})$ resulting from the seasonal Nile floods and composed of silt and fine sand dominated by quartz grains and heavy minerals. 


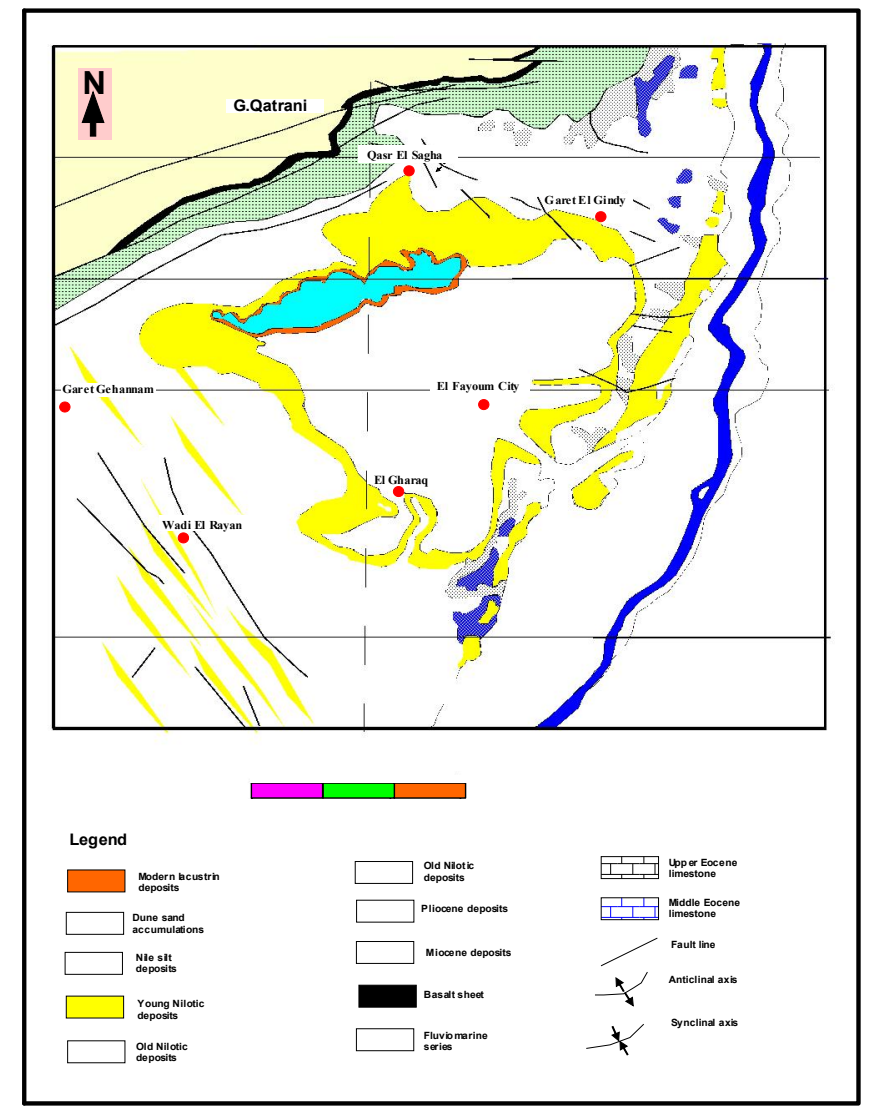

Fig. 2: Geologic map of El Fayoum area, Egypt (Tamer 1968 and El Sheikh 2004).

\subsection{Structural setting}

El Fayoum depression is a structurally-controlled tectonic basin, marked by northeast-striking faults along its northern margin. The structural setting of this depression can be divided into primary and tectonic structures. The primary structures include: stratification, graded-bedding and crossbedding, while tectonic structures include flexures, joints and faults (Kusky et al., 2011). Qarun Lake is located in the northern part of El Fayoum depression, at a right-step between two strands of the NE striking fault system. The E-W structures probably related to the relative motion between south Europe and north Egypt and closure of the Neotethys (Kusky and Ramadan 2002).

\subsection{Hydrogeological setting (aquifer systems)}

The main aquifer at El Fayoum depression is the Quaternary aquifer which generally composed of sand with high content of clay. However, it is more sandy and sometimes gravelly towards the west. The clay facies increase towards Qarun Lake due north and become calcareous due the southern part of the depression. Generally, the lithology shows great changes both in the lateral and vertical directions. Upper Eocene marl and limestone form the base of the Quaternary aquifer in the depression area, while it was bounded by the Middle Eocene limestone along the peripheries at east and west (El Sheikh, 2004). The maximum thickness of this aquifer is present in the center of the depression (SanhourIbshiway area) where it reaches $40 \mathrm{~m}$, while the minimum thickness is less than $1 \mathrm{~m}$ along the depression peripheries due to local faulting (El Sheikh, 2004).

The Quaternary groundwater generally flows from south to north and northwest directions in line with the directions of surface water flow in various canals (Fig. 3). The groundwater levels decrease from south and southeast towards west and northwest (i.e. from $+20 \mathrm{~m}$ to $-40 \mathrm{~m}$ close to Lake Qarun). The decrease in water levels follows the same trend of the general slope of the depression floor. Surface water constitutes the main recharging source for groundwater through direct seepage of irrigation water from irrigation network and/or cultivated lands. These recharging sources cause continuous rise of the groundwater levels in most of the depression area. On the other hand, Qarun Lake (-43 m) represents a 
natural discharging area for groundwater either from surface drains or subsurface flow under the effect of natural slope. This situation causes continuous rise of the lake level and hence vast parts of the cultivated lands and buildings are deteriorated particularly during winter season.

The high content of clay in the northern and eastern parts of El Fayoum depression reflects impervious conditions prevent the downward seepage of surface water. Consequently water logging is created very near the ground surface (El sheikh, 2004). Another cause of water logging is the usage of traditional irrigation methods such as flood irrigation which lead to formation of some bonds which cause serious damage in the new and old cultivated lands in El Fayoum (El Abd and El Osta, 2014).

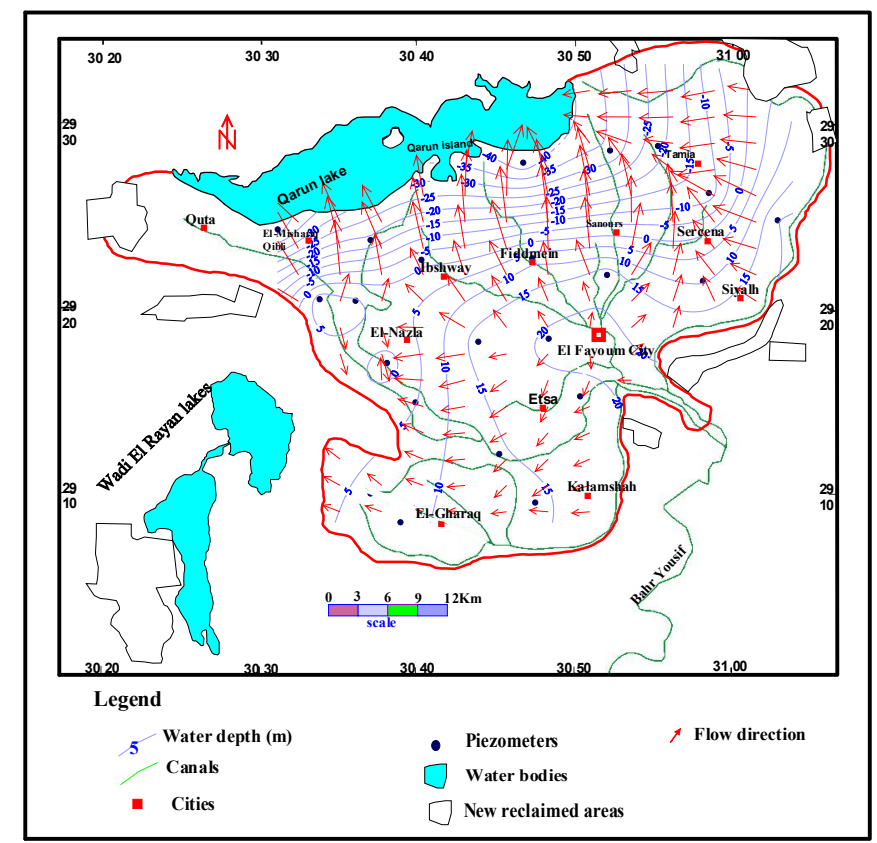

Fig. 3: Flow net map of the Quaternary aquifer, El Fayoum area, Egypt (El Sheikh, 2004)

\section{Materials and Methods}

To study the water quality assessment and deterioration in the study area, the following procedures were applied: (1) El Fayum topographic sheets at scale of 1:50,000 were used for the preparation of the base maps. (2) Field activities were conducted in 2018 including the collection of surface and groundwater samples to study their hydrochemical characteristics. The current research is based on the collection and analysis of twenty nine samples (11 surface water sample and 18 groundwater sample, see Fig. 1). The surface water samples include four samples from canals (Nos. 2, 4, 8, and 16), six samples from drains (Nos. 1, 3, 6, 7, 22, and 29) and one sample from Qarun Lake (sample No.5). These samples were analyzed for major constituents $\left(\mathrm{Ca}^{2+}, \mathrm{Mg}^{2+}, \mathrm{Na}^{+}, \mathrm{K}^{+}, \mathrm{SO}_{4}{ }^{2-}, \mathrm{Cl}^{-}\right.$in addition to $\mathrm{PO}_{4}{ }^{3-}$ and $\mathrm{NO}_{3}{ }^{-}$(Table 1). $\mathrm{PO}_{4}$ is not detected at all samples. The concentrations of these constituents were estimated using a Thermo Scientific Ion Chromatograph (IC), model Dionex, ICS1100. $\mathrm{CO}_{3}{ }^{2-}$ and $\mathrm{HCO}^{-}$were measured by titration using standard $\mathrm{HCl}$ solution. These analyses were conducted at Laboratories of the Desert Research Center (DRC) in Cairo, Egypt, according to the methods adopted by U. S. Geological Survey (ASTM. 2002). The ionic charge balance of these analyses was within $\pm 5 \%$. 
Table 1. Hydrochemical data of surface and groundwater samples collected from northeast El Fayoum area, Egypt. (Concen. expressed as mg/L)

\begin{tabular}{|c|c|c|c|c|c|c|c|c|c|c|c|c|c|}
\hline Sample no & $\mathbf{X}$ & $\mathbf{Y}$ & $\mathrm{Ca}$ & Mg & $\mathbf{K}$ & $\mathbf{N a}$ & $\mathrm{CO}_{3}$ & $\mathrm{HCO}_{3}$ & $\mathrm{Cl}$ & $\mathrm{SO}_{4}$ & TDS & E.C. & pH \\
\hline \multicolumn{14}{|c|}{ Canals } \\
\hline 2 & 30.90433 & 29.58488 & 107.7 & 39.3 & 13.7 & 315.3 & 0 & 219.6 & 400.9 & 401.3 & 1632 & 2640 & 7.5 \\
\hline 4 & 30.88907 & 29.51107 & 120.4 & 49.3 & 16.1 & 431.0 & 0 & 262.3 & 500.1 & 557.95 & 2100 & 3450 & 7.4 \\
\hline 8 & 30.86595 & 29.35497 & 39.7 & 13.2 & 6.6 & 48.0 & 0 & 152.5 & 50.8 & 64.6 & 299 & 680 & 7.1 \\
\hline 16 & 30.85757 & 29.38248 & 36.5 & 13.4 & 6.0 & 44.1 & 0 & 152.5 & 32.0 & 58.7 & 257 & 620 & 7.4 \\
\hline \multicolumn{14}{|c|}{ Drains } \\
\hline 1 & 30.90185 & 29.58655 & 211.9 & 41.0 & 33.0 & 896.3 & 0 & 146.4 & 1108.6 & 1145.1 & 4009 & 5580 & 7.3 \\
\hline 3 & 30.91617 & 29.53917 & 129.4 & 72.3 & 27.6 & 915.2 & 0 & 183 & 1340.7 & 898.9 & 3476 & 6000 & 7.6 \\
\hline 6 & 30.79885 & 29.47597 & 71.7 & 49.2 & 12.3 & 291.0 & 0 & 325.1 & 374.1 & 414.1 & 1370 & 2460 & 7.5 \\
\hline 7 & 30.843 & 29.48345 & 110.7 & 54.0 & 14.1 & 319.4 & 0 & 450.2 & 400.4 & 463.4 & 1649 & 3000 & 7 \\
\hline 22 & 30.8618 & 29.49867 & 139.2 & 71.1 & 13.3 & 312.5 & 0 & 244 & 446.3 & 535.9 & 1590 & 2720 & 7.7 \\
\hline 29 & 30.87315 & 29.45982 & 109.7 & 53.7 & 8.5 & 265.3 & 0 & 268.4 & 321.8 & 424.6 & 1268 & 2180 & 7.7 \\
\hline \multicolumn{14}{|c|}{ Qarun Lake } \\
\hline 5 & 30.80608 & 29.47917 & 501.2 & 1158 & 244 & 10282 & 30 & 176.9 & 21104 & 11779 & 35103 & 54848 & 8.5 \\
\hline \multicolumn{14}{|c|}{ Groundwater (Quaternary aquifer) } \\
\hline 9 & 30.8635 & 29.3664 & 148.8 & 114 & 9.1 & 255.4 & 0 & 341.6 & 471.6 & 558.6 & 1694 & 2930 & 6.6 \\
\hline 10 & 30.86488 & 29.4056 & 118.3 & 156 & 9.8 & 588.1 & 0 & 695.4 & 856.9 & 608.1 & 3084 & 5180 & 8.3 \\
\hline 11 & 30.8641 & 29.40332 & 89.3 & 35.8 & 4.6 & 585.8 & 0 & 805.2 & 356.6 & 442.5 & 1917 & 3420 & 8.9 \\
\hline 12 & 30.85392 & 29.37058 & 68.0 & 52.5 & 19.7 & 123.8 & 0 & 366 & 147.4 & 284.4 & 1079 & 2150 & 6.3 \\
\hline 13 & 30.85272 & 29.37847 & 40.6 & 72.4 & 13.2 & 438.7 & 0 & 549 & 294.6 & 516.3 & 1580 & 2850 & 8.6 \\
\hline 14 & 30.85293 & 29.38208 & 60.4 & 37.9 & 11.5 & 81.6 & 0 & 396.5 & 104.3 & 80.5 & 575 & 1390 & 7.9 \\
\hline 15 & 30.85738 & 29.38232 & 122.7 & 126 & 27.7 & 554.1 & 0 & 603.9 & 601.2 & 803.5 & 2568 & 4410 & 7.9 \\
\hline 17 & 30.84762 & 29.4191 & 78.8 & 96.9 & 5.0 & 218.7 & 0 & 512.4 & 272.4 & 381.4 & 1260 & 2330 & 7.9 \\
\hline 18 & 30.84485 & 29.42078 & 46.6 & 53.7 & 9.2 & 529.1 & 0 & 719.8 & 354.9 & 526.6 & 1880 & 3220 & 8.6 \\
\hline 19 & 30.8311 & 29.42075 & 69.8 & 54.0 & 8.7 & 248.2 & 0 & 549 & 186.8 & 247.9 & 1090 & 2180 & 8.2 \\
\hline 20 & 30.82068 & 29.42357 & 78.6 & 64.9 & 12.2 & 309.3 & 0 & 445.3 & 310.8 & 409.8 & 1338 & 2460 & 8 \\
\hline \multicolumn{14}{|c|}{ Groundwater (Quaternary aquifer) } \\
\hline 21 & 30.81347 & 29.43537 & 76.2 & 81.2 & 31.6 & 887.9 & 0 & 854 & 649.0 & 803.5 & 2956 & 5200 & 8.5 \\
\hline 23 & 30.85353 & 29.50208 & 226.7 & 133 & 111 & 715.4 & 0 & 378.2 & 1166.8 & 1074.6 & 4217 & 5850 & 7.6 \\
\hline 24 & 30.8568 & 29.49442 & 342.8 & 281 & 20.4 & 1727.5 & 0 & 750.3 & 2846 & 1559.6 & 8953 & 13150 & 7.4 \\
\hline 25 & 30.8864 & 29.43255 & 73.7 & 22.2 & 6.1 & 447.5 & 0 & 396.5 & 231.8 & 706.2 & 1606 & 2850 & 8.1 \\
\hline 26 & 30.8959 & 29.44537 & 230.1 & 102 & 35.5 & 1290.9 & 0 & 439.2 & 1322.6 & 1863.4 & 5964 & 8340 & 7.6 \\
\hline 27 & 30.89538 & 29.44545 & 121.9 & 53.9 & 39.0 & 639.9 & 0 & 500.2 & 601.6 & 768.4 & 2365 & 4250 & 8.1 \\
\hline 28 & 30.89333 & 29.44392 & 73.7 & 27.7 & 10.4 & 173.8 & 0 & 390.4 & 107.1 & 268.5 & 1036 & 2040 & 8.2 \\
\hline
\end{tabular}




\section{Results and Discussion}

\subsection{Hydrogeochemical characteristics of groundwater \\ 5.1.1. Water salinity}

The salinity of surface water in canals range from 256 to 299 ppm (samples 16 and 8, respectively) indicating fresh water because these canals are recharged from River Nile water. Furthermore, canals represented by samples Nos. 2 and 4 have brackish water (1631 and 2099 ppm, respectively) because they gain more salinity by leaching and dissolution of clay deposits. On turn, the salinity of drains water vary between 1370 ppm (sample No. 6) and 4009 ppm (sample No. 1) which indicate brackish water category because drains continuously receive soluble salts from land washing and drainage. Furthermore, the water sample of Qarun Lake has salinity of 48,186 ppm which is higher than the salinity of Mediterranean and Red seas and is classified as hyper saline due to the evapoconcentration process (Abdel Wahed et al., 2014).

The salinity of the Quaternary groundwater in north-eastern part of El Fayoum ranges from 574 ppm (sample No. 14) to 8953ppm (sample No. 24). This indicates fresh to brackish water with only two saline samples (Nos. 24 and 26) located east of Sinores City (see Fig 1). The high salinity of these water samples may be due to over-pumping and/or closeness to Lake Qarun. According to Chebotarev's 1955, the Quaternary groundwater of the study area can be classified as fresh to brackish water since their salinities are less than $5000 \mathrm{ppm}$. Furthermore, the salinity increases generally towards the north and northwest towards Qarun Lake (Fig. 4) and this may cause soil salinization for lands located south of the lake. The remote sensing study of El Baroudy (2013) shows that the high sensitive areas for desertification in El Fayoum depression are found in the southern parts of Qarun Lake and they exhibit an area of $54.09 \%$ of the total depression area. The area of the lake itself represents only $18.31 \%$ of the depression area. This means that more than half of El Fayoum depression including the study area will suffer from the threat of desertification during the next few decades.

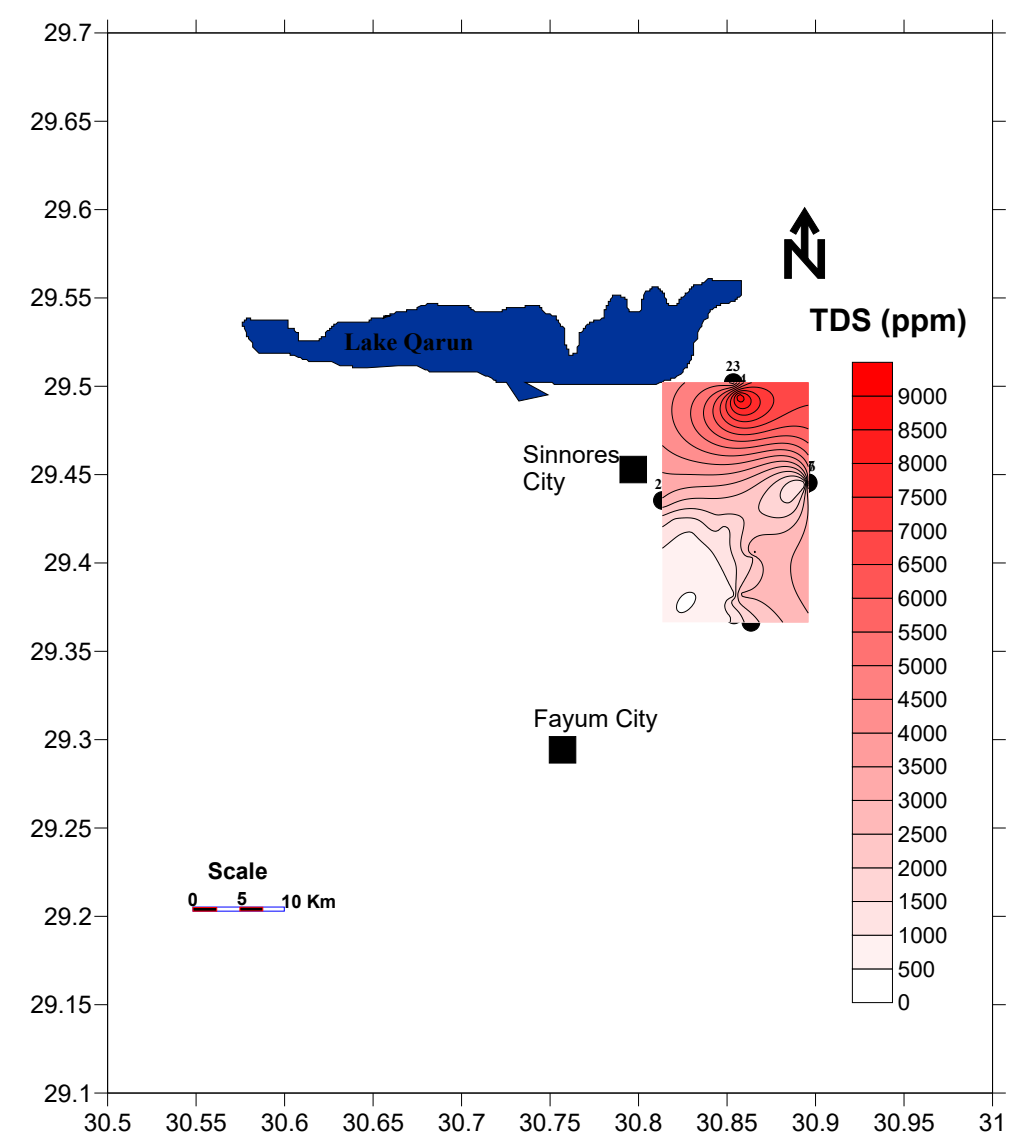

Fig. 4: Iso salinity zonation map, north-east El Fayoum depression area, Egypt. 


\subsubsection{Water type}

The most dominant water type is $\mathrm{Cl}-\mathrm{Na}$ which represented by $44 \%$ of groundwater samples. It characterizes the groundwater with the highest salinity and it represents an advanced stage of metasomatism in groundwater. $28 \%$ of samples have $\mathrm{HCO}_{3}-\mathrm{Na}$ water type indicating the meteoric origin due to direct recharge from surface water canals. The third water type is $\mathrm{SO}_{4}-\mathrm{Na}$ which represented by $28 \%$ of samples and may reveal dissolution of terrestrial salts (such as gypsum).

\subsubsection{Ionic dominance}

The order of cationic dominance in the Quaternary groundwater at north-east El-Fayoum City area are $\mathrm{Na}^{+}>\mathrm{Mg}^{2+}>\mathrm{Ca}^{2+}$ at $72 \%$ of samples and $\mathrm{Na}^{+}>\mathrm{Ca}^{2+}>\mathrm{Mg}^{2+}$ at the rest of samples. In turn, the order of anions sequence are $\mathrm{Cl}^{-}>\mathrm{SO}_{4}{ }^{2-}>\mathrm{HCO}_{3}{ }^{-}\left(44 \%\right.$ of samples), $\mathrm{SO}_{4}{ }^{2-}>\mathrm{HCO}_{3}{ }^{-}\left(\mathrm{Cl}^{-}\right)>\mathrm{Cl}^{-}$ $\left(\mathrm{HCO}_{3}{ }^{-}\right)\left(28 \%\right.$ of samples) and $\mathrm{HCO}_{3}>\mathrm{SO}_{4}{ }^{2-}\left(\mathrm{Cl}^{-}\right)>\mathrm{Cl}^{-}\left(\mathrm{SO}_{4}{ }^{2-}\right)$ at $28 \%$ of samples. The anion sequence $\mathrm{Cl}^{-}>\mathrm{SO}_{4}{ }^{2-}>\mathrm{HCO}_{3}{ }^{-}$represents an advanced stage of metasomatism in groundwater, while the sequence $\mathrm{HCO}_{3}>\mathrm{SO}_{4}{ }^{2-}\left(\mathrm{Cl}^{-}\right)>\mathrm{Cl}^{-}\left(\mathrm{SO}_{4}{ }^{2-}\right)$ represent low stage of metasomatism (mineralization).

\subsection{Trace elements content and pollution}

There is no pollution with $\mathrm{Ag}, \mathrm{Cd}, \mathrm{Cr}, \mathrm{Mo}, \mathrm{Ni}$ and $\mathrm{Zn}$ because their concentrations are less than their maximum permissible limits (Table 2). Both surface and groundwater are polluted with Al due to the presence and dissolution of clay materials in the aquifer matrix. The boron concentration in surface water is less than the maximum permissible limit of $0.5 \mathrm{mg}$, so surface water is not contaminated with boron except samples 3 (Industrial drain) and 5 (Lake Qarun). Groundwater of the Quaternary aquifer is not contaminated with boron except samples Nos. 24 and 26. The Fe concentration in surface water system range between $0.208 \mathrm{mg} / 1$ (sample No. 1, agricultural drain 1) and $3.96 \mathrm{mg} / 1$ (sample No. 22, El Bats Drain). This means that the surface water system is polluted with iron (except drain 1). On the other hand, the Quaternary groundwater has values of Fe concentration more than the maximum permissible limit of iron $(0.3 \mathrm{mg} / \mathrm{l}$ according to the guidelines of the Egyptian Higher committee of Water (EHCW, 2007) and World Health Organization (WHO, 2011). Again, the Quaternary groundwater is contaminated with iron except sample 23 which has Fe content of $0.067 \mathrm{mg} / \mathrm{l}$. The origin of $\mathrm{Fe}$ is geogenic due to the presence of pyritic clay in the aquifer matrix. The Mn concentration in surface water ranges between 0.0173 and $0.2886 \mathrm{mg} / \mathrm{l}$, which less than the maximum permissible limit of $\mathrm{Mn}(0.4 \mathrm{mg} / \mathrm{l})$. This indicates that surface water is not polluted with $\mathrm{Mn}$ and the Quaternary groundwater is not polluted with Mn as well except samples 12, 14, 17, 20 and 24.

The waters of canals are not polluted with lead $(\mathrm{Pb})$ except canal 4 , while half of water samples collected from drains is polluted with $\mathrm{Pb}$ since they have $\mathrm{Pb}$ concentration more than the maximum permissible limit $(0.01 \mathrm{mg} / \mathrm{l})$. For groundwater, all samples are polluted with $\mathrm{Pb}$ which has anthropogenic origin from combustion of fuel or ceramic industry. The surface and groundwater are polluted with Sr metal.

\subsection{Anthropogenic impacts}

\subsubsection{Agricultural impacts on water quality}

Chemicals of serious concern in groundwater quality degradation by agriculture activities are phosphates and nitrates. The chemical analyses results for the water samples collected from north-east El Fayoum area indicate the absence of phosphate in the surface and groundwater systems. This means that farmers in the study area do not use phosphate fertilizers or apply them at limited scale in agricultural activities.

On the other hand, the nitrate concentrations at surface water range between 0.61 and 10.497 $\mathrm{mg} / \mathrm{l}$, while their concentrations at the groundwater range between 0.293 and $14.288 \mathrm{mg} / \mathrm{l}$ (Table 3). This means that the application of nitrate fertilizers is common in the study area but the nitrate content in groundwater is still lower than the maximum permissible limit for human drinking $(50 \mathrm{mg} / \mathrm{l})$. 
Inter. J of Envi., 9(3): 171-184, 2020

Table 2: Concentrations of trace elements for surface and groundwater samples collected from northeast El Fayoum area, Egypt.

\begin{tabular}{|c|c|c|c|c|c|c|c|c|c|c|c|c|c|c|c|c|}
\hline $\begin{array}{c}\text { Sample } \\
\text { No. }\end{array}$ & $\begin{array}{c}\text { Water } \\
\text { Point } \\
\text { type }\end{array}$ & Ag & Al & B & $\begin{array}{c}\text { Cd } \\
0.05\end{array}$ & Co & $\begin{array}{c}\mathrm{Cr} \\
\mathbf{0 . 0 5}\end{array}$ & $\begin{array}{l}\mathrm{Cu} \\
\mathbf{0 . 1}\end{array}$ & $\begin{array}{l}\mathrm{Fe} \\
0.3\end{array}$ & $\begin{array}{l}\text { Mn } \\
0.4\end{array}$ & Mo & $\mathbf{N i}$ & $\begin{array}{l}\text { Pb } \\
0.05\end{array}$ & Si & $\mathrm{Sr}$ & $\begin{array}{l}\mathrm{Zn} \\
0.5\end{array}$ \\
\hline 1 & Drain & 0.0033 & 12.91 & 0.4065 & 0.0007 & 0.0004 & n.d & 0.0141 & 0.2083 & 0.0173 & 0.0066 & 0.0048 & 0.0032 & 1.66 & 2.154 & 0.0224 \\
\hline 2 & Canal & 0.027 & 40.93 & 0.4507 & 0.0008 & 0.0011 & n.d & 0.1071 & 0.842 & 0.1038 & 0.0068 & 0.0093 & 0.007 & 3.77 & 1.575 & $\underline{0.518}$ \\
\hline 3 & Drain & n.d & 44.73 & 0.8225 & 0.0013 & 0.0004 & n.d & 0.1596 & 0.9011 & 0.0333 & 0.0057 & 0.0122 & n.d & 0.2286 & 5.436 & $\overline{0.0253}$ \\
\hline 4 & Canal & n.d & 54.1 & 0.0357 & 0.0009 & 0.0019 & n.d & 0.106 & 2.369 & 0.1551 & 0.0071 & 0.0129 & 0.0142 & 6.041 & 2.324 & 0.0328 \\
\hline 5 & Qarun L. & 0.0254 & 30.42 & $\underline{3.104}$ & 0.0013 & n.d & n.d & 0.0639 & 0.3745 & 0.0882 & 0.0054 & 0.0046 & 0.0077 & 2.949 & 12.49 & 0.0096 \\
\hline 6 & Drain & 0.0005 & 61.34 & 0.2171 & 0.0012 & 0.0008 & 0.0246 & 0.1791 & 1.356 & 0.1141 & 0.0081 & 0.0117 & 0.0077 & 4.598 & 1.026 & 0.0292 \\
\hline 7 & Drain & n.d & 27.89 & 0.0459 & 0.0011 & 0.0013 & 0.0056 & 0.0477 & 0.9983 & 0.2886 & 0.0059 & 0.0081 & 0.0125 & 4.216 & 1.496 & 0.181 \\
\hline 8 & Canal & n.d & 45.28 & 0.1181 & 0.0004 & 0.0006 & n.d & 0.975 & 1.301 & 0.0991 & 0.0012 & 0.0082 & n.d & 1.413 & 0.3901 & 0.0199 \\
\hline 10 & Groundw. & 0.025 & 68.32 & 0.1755 & 0.002 & 0.0001 & 0.0387 & 0.01242 & 0.7985 & 0.1824 & 0.0013 & 0.0166 & 0.0325 & 12.6 & 2.12 & 0.1977 \\
\hline 11 & Groundw. & n.d & $\overline{73.18}$ & 0.1401 & 0.0006 & 0.0003 & n.d & 0.2213 & 1.035 & 0.1892 & 0.0295 & 0.0131 & 0.0246 & 11.04 & 0.438 & 0.0298 \\
\hline 12 & Groundw. & 0.0099 & 45.22 & 0.1291 & 0.0012 & 0.0001 & n.d & 0.1167 & 1.640 & 0.6959 & 0.0041 & 0.008 & 0.0151 & 6.321 & 2.153 & 0.038 \\
\hline 13 & Groundw. & n.d & 22.22 & 0.2666 & 0.001 & 0.0003 & n.d & 0.1215 & 0.5038 & 0.2963 & 0.0268 & 0.005 & 0.036 & 8.784 & 1.315 & 0.0192 \\
\hline 14 & Groundw. & 0.0052 & 42.41 & 0.1319 & 0.001 & 0.0012 & n.d & 0.1282 & 0.3906 & 2.309 & 0.0007 & 0.0097 & 0.0228 & 9.198 & 1.401 & 0.0425 \\
\hline 15 & Groundw. & $\underline{0.0336}$ & 49.14 & 0.2939 & 0.0003 & 0.0091 & 0.0079 & 0.04 & $\underline{13.35}$ & 0.966 & 0.0131 & 0.0191 & 0.0334 & 12.41 & 2.211 & 0.0373 \\
\hline 16 & Canal & $\overline{0.0298}$ & 53.88 & 0.1374 & 0.0001 & 0.002 & 0.0317 & 0.1139 & 2.34 & 0.1395 & 0.0013 & 0.0121 & 0.0018 & 2.844 & 0.3477 & 0.027 \\
\hline 17 & Groundw. & 0.008 & 48.18 & 0.1923 & 0.0014 & 0.0008 & n.d & 0.0486 & 0.7007 & 0.9993 & 0.0136 & 0.0111 & 0.0309 & 11.6 & 1.256 & 0.0482 \\
\hline 18 & Groundw. & 0.0076 & 66.82 & 0.1511 & 0.001 & 0.0013 & $\underline{0.0698}$ & 0.134 & 1.296 & 0.381 & $\underline{0.1073}$ & 0.0126 & 0.0286 & 11.36 & 0.583 & 0.0616 \\
\hline 19 & Groundw. & n.d & 11.76 & 0.2226 & 0.0004 & 0.0054 & n.d & 0.1196 & 4.777 & 0.2969 & 0.003 & 0.0183 & 0.0634 & 17.02 & 0.6941 & 0.0784 \\
\hline 20 & Groundw. & 0.0199 & 20.98 & 0.0274 & 0.001 & 0.0006 & n.d & 0.1848 & 0.5383 & 0.4161 & 0.0172 & 0.004 & 0.0252 & $\overline{8.763}$ & 1.314 & 0.0426 \\
\hline 21 & Groundw. & n.d & 36.53 & 0.2446 & 0.0012 & 0.0005 & n.d & 0.1177 & 0.9026 & 0.1265 & 0.0706 & 0.0091 & 0.0413 & 15.23 & 1.464 & 0.0743 \\
\hline 22 & Drain & n.d & 101.8 & 0.0934 & 0.0014 & 0.0029 & n.d & 0.2136 & 3.965 & 0.2306 & 0.0074 & $\underline{0.0217}$ & 0.0121 & 7.767 & 1.668 & 0.0583 \\
\hline 23 & Groundw. & n.d & 12.27 & 0.0436 & 0.0014 & 0.0022 & 0.0033 & 0.0261 & 0.067 & 0.2882 & 0.0479 & $\overline{0.0212}$ & 0.0352 & n.d & 1.604 & 0.0348 \\
\hline 24 & Groundw. & n.d & 50.97 & 0.5375 & 0.0014 & 0.0063 & 0.0494 & 0.172 & 8.616 & 3.801 & 0.0084 & 0.017 & $\underline{0.0766}$ & 16.64 & 11.72 & 0.2274 \\
\hline 25 & Groundw. & n.d & 30.66 & 0.2638 & 0.0003 & n.d & n.d & 0.158 & 0.2232 & $\overline{0.0244}$ & 0.0192 & 0.006 & $\overline{0.0443}$ & 15.78 & 1.677 & 0.0126 \\
\hline 26 & Groundw. & n.d & 20.26 & 0.7047 & 0.0014 & 0.0005 & n.d & 0.0744 & 0.3697 & 0.1581 & 0.0072 & 0.0058 & 0.0244 & 9.212 & 10.93 & 0.0545 \\
\hline 27 & Groundw. & n.d & 39.3 & 0.0823 & 0.001 & 0.0007 & n.d & 0.0974 & 0.4729 & 0.0722 & 0.0118 & 0.0094 & 0.0254 & 9.434 & 4.713 & 0.0452 \\
\hline 28 & Groundw. & 0.017 & 48.57 & 0.0879 & 0.0008 & n.d & n.d & 0.1062 & 0.6663 & 0.0781 & 0.0046 & 0.0086 & 0.0185 & 7.929 & 18.78 & 0.1219 \\
\hline 29 & Drain & n.d & 51.87 & 0.2226 & 0.1119 & 0.0011 & n.d & 0.0179 & 1.375 & 0.1878 & 0.0095 & 0.0121 & 0.0118 & 4.959 & 1.089 & 0.0277 \\
\hline
\end{tabular}

Groundw.= groundwater/ Qarun L.= Qarun Lake/ n.d=not detected/ Underlined numbers=maximum concentration/ The number under each chemical symbol represents the maximum permissible limit. 
Table 3: Phosphate and nitrate concentration in surface and groundwater samples collected from north east El Fayoum area, Egypt.

\begin{tabular}{|c|c|c|c|c|c|}
\hline Sample No & $\mathrm{PO}_{4}{ }^{3-}$ & $\mathrm{NO}_{3}^{-}$ & Sample No & $\mathrm{PO}_{4}{ }^{3-}$ & $\mathrm{NO}_{3}^{-}$ \\
\hline \multicolumn{3}{|c|}{ Surface water (Canals) } & \multicolumn{3}{|c|}{ Quaternary groundwater } \\
\hline 2 & N.d. & 10.479 & 10 & N.d. & 4.131 \\
\hline 4 & N.d. & N.d. & 11 & N.d. & N.d. \\
\hline 8 & N.d. & 1.924 & 12 & N.d. & N.d. \\
\hline \multirow[t]{2}{*}{16} & N.d. & 4.006 & 13 & N.d. & 0.516 \\
\hline & drains & & 14 & N.d. & 6.081 \\
\hline 1 & N.d. & 7.802 & 15 & N.d. & N.d. \\
\hline 3 & N.d. & 0.610 & 17 & N.d. & 0.293 \\
\hline 6 & N.d. & N.d. & 18 & N.d. & 0.475 \\
\hline 7 & N.d. & 4.544 & 19 & N.d. & 6.546 \\
\hline 22 & N.d. & 1.366 & 20 & N.d. & 8.227 \\
\hline \multirow{2}{*}{29} & N.d. & N.d. & 21 & N.d. & N.d. \\
\hline & Lake Qarun & & 23 & N.d. & 9.149 \\
\hline \multirow[t]{5}{*}{5} & N.d. & N.d. & 24 & N.d. & 1.000 \\
\hline & & & 25 & N.d. & 7.040 \\
\hline & & & 26 & N.d. & 9.810 \\
\hline & & & 27 & N.d. & 14.289 \\
\hline & & & 28 & N.d. & 2.319 \\
\hline
\end{tabular}

N.d.= Not detected.

\subsubsection{Industrial impacts on water quality}

In El Fayoum Governorate, a number of factories located due the north in Kom Oshim industrial zone (1- Pharos [Enova] ceramic Co., 2- El Nasr for Chemical industries [pesticides], 3- Brick factory, 4- Misr-El Fayoum Co for construction materials, 5- Vegetable Oils Co., 6- North Sinai Company for Manganese industry) contribute to the industrial sewerage network (for example, the drain represented by sample 3). These factories discharge their untreated or partially treated effluent directly to the industrial or agricultural drains and they are often the sources of environmental pollution for water and air (especially the ceramic industry which can cause lead $(\mathrm{Pb})$ toxicity).

\subsection{Removal of heavy metals using some clay minerals}

Traditional heavy metal removal procedures such as chemical precipitation, ion exchange, solvent extraction, and electrochemical deletion can be used. These processes have significant drawbacks, such as incomplete elimination, increased-energy requirements, and the production of hazardous sludge. Many approximations have recently been examined for the expansion of low-cost and extra-useful technologies, jointly to reduce wastewater formation and improve the quality of the handled effluent. Adsorption has grown to be one of the uncommon therapies, and in recent years, there has been a big search for low-cost adsorbents with metal-required capacities. Scientific knowledge is currently being offered a great amount of information regarding several adsorbents capable of selectively removing severe metal ions from hydrous mixes. Scientists have demonstrated an increase in interest in normal source adsorbents in recent decades. Normal sorbents are resources that occur in the environment and whose use does not convey any additional contaminants. Sedimentary rocks, peat, coffee grinds, lignin, olive gravels, and various minerals are examples of selective adsorbents from natural sources.

Heavy metal removal effectiveness is mostly determined by the chemical structure and number of active sites of the adsorbent. Figure 5 depicts the effect of adsorbent dosage on $\mathrm{Cu}^{2+}$ ion removal effectiveness. According to the graph, increasing the adsorbent dose enhanced the removal effectiveness up to $92 \%$ at $15 \mathrm{~g} / \mathrm{l}$. This trend of increases is due to the increase in the active sites and functional groups as a function of adsorbent dose increase. Figure 6 shows the effects of contact time on the removal efficiency of $\mathrm{Cu}$ (II). Due to the large number of vacant adsorption sites, metal uptake was rapid at first; all active sites were occupied by target $\mathrm{Cu}$ (II) within 2 hours, after which the adsorption rate gradually became almost constant at equilibrium to achieve equilibrium conditions where the concentration of adsorbate in the bulk solution was in dynamic balance with that at the interface. Some 
of the clay's adsorption sites may have been easily obtained due to increases in functional groups on its surface.

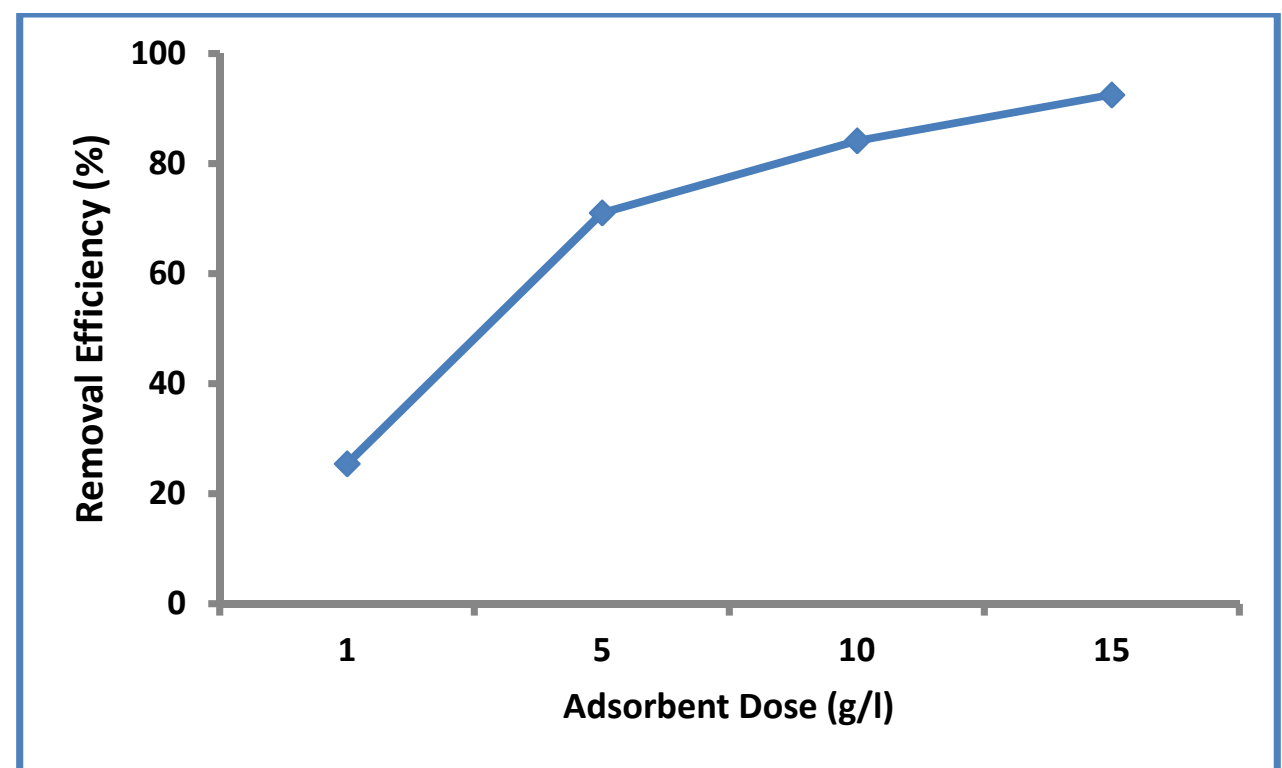

Fig. 5: Effect of adsorbent dose (g/l) on the removal efficiency of cupper (II) ion at initial concentration of $100 \mathrm{mg} / \mathrm{l}$.

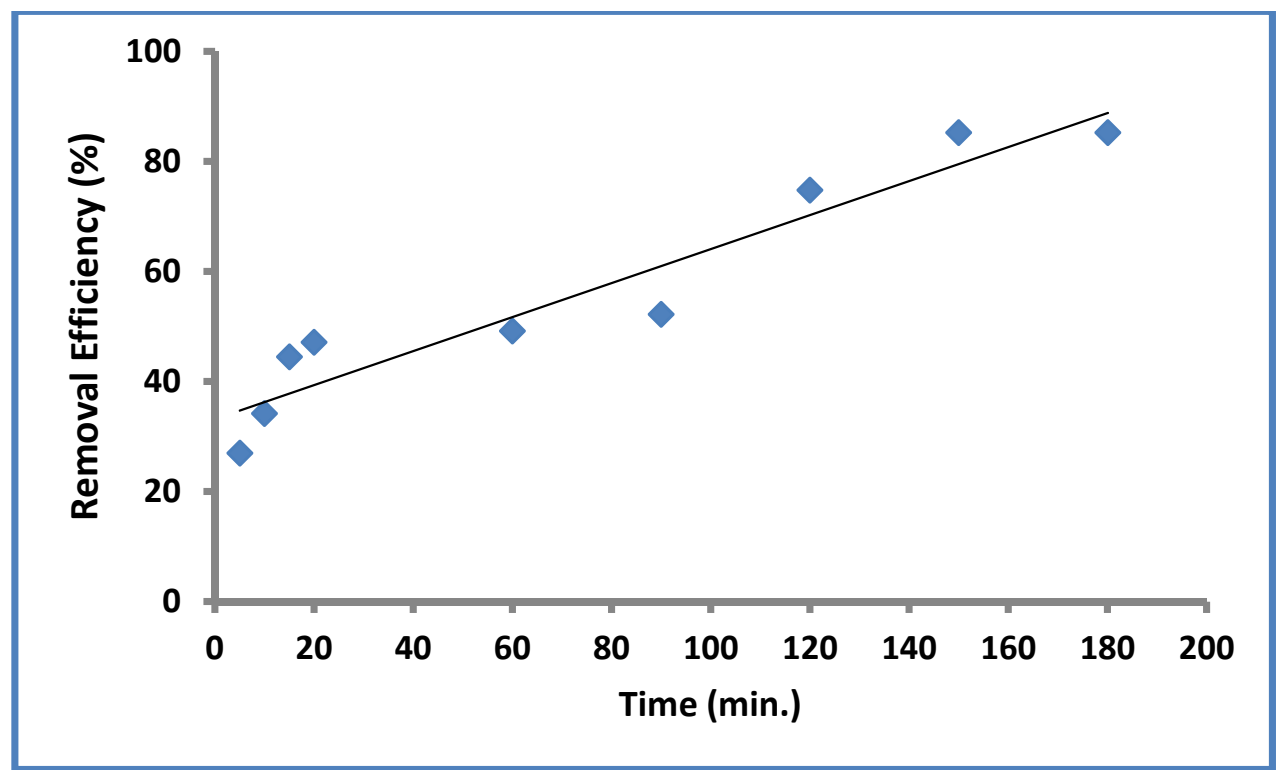

Fig. 6: Effect of contact time on the removal efficiency of cupper (II) ion at initial concentration of 100 $\mathrm{mg} / \mathrm{l}$.

\subsection{Multivariate statistical analysis}

The statistical analysis can be used as a tool to detect the hydrogeochemical processes affecting groundwater quality. Two kinds of statistical analyses are used at the current study as follows:

\subsubsection{Correlation matrix analysis}

The Pearson's correlation coefficients ( $r$ ) of physicochemical parameters of groundwater quality are shown in Table (4) and they are used for correlation analysis at the current study. Correlation between water quality parameters can facilitate the task of water quality monitoring. A high correlation coefficient (r) near 1 means a good positive relationship between two variables, when (r) value is close to -1 this means a good negative relationship between them and finally when its value is around zero, 
this means no relationship between them at a significant level of $<0.05$. More precisely, it can be said that parameters showing $r>0.75$ are considered to be strongly correlated, whereas ( $r$ ) value between 0.5 and 0.75 shows moderate correlation and $(\mathrm{r})$ values between 0.5 and 0.3 indicate weak correlation (Wang et al., 2007).

The correlation matrix (see table 4 ) shows a positively strong correlation between TDS and $\mathrm{Ca}^{2+}$ $(\mathrm{r}=0.92), \mathrm{Mg}^{+2}(\mathrm{r}=0.87), \mathrm{Na}(\mathrm{r}=0.96), \mathrm{SO}_{4}{ }^{2-}(\mathrm{r}=0.85)$ and $\mathrm{Cl}^{-}(\mathrm{r}=0.96)$. This finding indicates that these components (especially $\mathrm{Na}^{+}$and $\mathrm{Cl}^{-}$) are the main factors contributing to the emerging groundwater salinization. On turn, TDS is weakly correlates with $\mathrm{HCO}_{3}{ }^{-}(\mathrm{r}=0.32)$ and $\mathrm{K}^{+}(\mathrm{r}=0.37)$. There is a strong correlation between $\mathrm{Ca}^{2+}$ and $\mathrm{SO}_{4}{ }^{2-}(\mathrm{r}=0.78)$ refers to sulfates (gypsum and anhydrite) dissolution, while the moderate correlation between $\mathrm{Mg}^{2+}$ and $\mathrm{SO}_{4}{ }^{2-}(\mathrm{r}=0.56)$ is indicative to epsomite $\left(\mathrm{MgSO}_{4} 7 \mathrm{H}_{2} \mathrm{O}\right)$ dissolution or use of $\mathrm{MgSO}_{4}$ fertilizers at the agricultural activities. Furthermore, the weak correlation between $\mathrm{Ca}^{2+}$ and $\mathrm{HCO}_{3}^{-}(\mathrm{r}=0.067)$ indicate a limited role of carbonate $\left(\mathrm{CaCO}_{3}\right)$ dissolution in controlling the groundwater composition in north east El Fayoum area. Moreover, the moderate correlation between $\mathrm{Na}^{+}$and $\mathrm{HCO}_{3}^{-}(\mathrm{r}=0.50)$ may refers to leaching of organic matter. The moderate correlation between $\mathrm{SO}_{4}{ }^{2-}$ and $\mathrm{Cl}^{-}(\mathrm{r}=0.68)$ can reflect the impact of the aquifer fluviomarine depositional environment. Finally, there is a strong correlation between $\mathrm{Na}$ and both of $\mathrm{Ca}$ and $\mathrm{Mg}$, this imply the prevalence of ion exchange at the Quaternary aquifer environment.

Table 4: Pearson correlation matrix of the hydrochemical variables of the Quaternary groundwater, NE El Fayoum area, Egypt

\begin{tabular}{lllllllllll}
\hline & $\mathbf{C a}$ & $\mathbf{M g}$ & $\mathbf{N a}$ & $\mathbf{K}$ & $\mathbf{C O}_{3}$ & $\mathbf{H C O}_{3}$ & $\mathbf{S O}_{4}$ & $\mathbf{C l}$ & $\mathbf{T D S}$ & $\mathbf{p H}$ \\
\hline $\mathbf{C a}$ & 1 & & & & & & & & & \\
$\mathbf{M g}$ & $.834^{* *}$ & 1 & & & & & & & & \\
$\mathbf{N a}$ & $.806^{* *}$ & $.760^{* *}$ & 1 & & & & & & \\
$\mathbf{K}$ & $.482^{*}$ & .201 & .314 & 1 & & & & & & \\
$\mathbf{C O}$ &. $\mathrm{a}$ &. $\mathrm{a}$ &. $\mathrm{a}$ &. $\mathrm{a}$ &. $\mathrm{a}$ & & & & & \\
$\mathbf{H C O}$ & .067 & .338 & $.500^{*}$ & $.182-$ &. $\mathrm{a}$ & 1 & & & & \\
$\mathbf{S O}_{4}$ & $.779^{* *}$ & $.563^{*}$ & $.836^{* *}$ & $.482^{*}$ &. $\mathrm{a}$ & .068 & 1 & & & \\
$\mathbf{C l}$ & $.914^{* *}$ & $.931^{* *}$ & $.877^{* *}$ & .291 &. $\mathrm{a}$ & .296 & $.679^{* *}$ & 1 & & \\
$\mathbf{T D S}$ & $.920^{* *}$ & $.866^{* *}$ & $.962^{* *}$ & .375 &. $\mathrm{a}$ & .323 & $.849^{* *}$ & $.958^{* *}$ & 1 & - \\
$\mathbf{p H}$ & -.370 & -.272 & .042 & .176 &. $\mathrm{a}$ & $.582^{*}$ & -.186 & $-.233-$ & -.163 & 1 \\
\hline HH $^{*}$
\end{tabular}

**. Correlation is significant at the 0.01 level *. Correlation is significant at the 0.05 level

a. Cannot be computed because at least one of the variables is constant.

\subsubsection{Hierarchical cluster analysis}

The drawn dendrogram shows the clusters based on the groundwater chemistry. According the dendrogram of Quaternary groundwater (Fig. 7), it is clear that there are two main clusters, the first one (cluster I) include TDS alone, while the second cluster (cluster II) include the major cations and anions that contribute in the chemical composition of groundwater beside the $\mathrm{pH}$. These two clusters are connected together because the degree of salinity indicated by TDS value could related and correlated with the dissolutions of major ions through ion exchange, redox reactions and water-rock interactions. Moreover, as the concentrations of the major ions increase, the TDS value increase. Furthermore, the cluster II is subdivided into three sub-clusters (A, B and C). The first sub-cluster (II A) include $\mathrm{Ca}^{2+}$ and $\mathrm{Mg}^{2+}$ in addition to $\mathrm{K}^{+}, \mathrm{CO}_{3}{ }^{2-}$ and $\mathrm{pH}$ which indicate the ion exchange process. The second subcluster (II B) includes the major ions $\left(\mathrm{Na}^{+}, \mathrm{HCO}_{3}^{-}, \mathrm{SO}_{4}{ }^{2-}\right)$ which are responsible for salinization process $\left(\mathrm{Na}^{+}, \mathrm{SO}_{4}{ }^{2-}\right)$ and fresh recharge from the surface water systems $\left(\mathrm{HCO}_{3}{ }^{-}\right)$which get recharged from the Nile water. The third sub-cluster (II C) composed of $\mathrm{Cl}^{-}$only and it represents the most element responsible for water salinity and the most conservative element in the groundwater environment because it does not involved in many hydrogeochemical processes and reactions. 


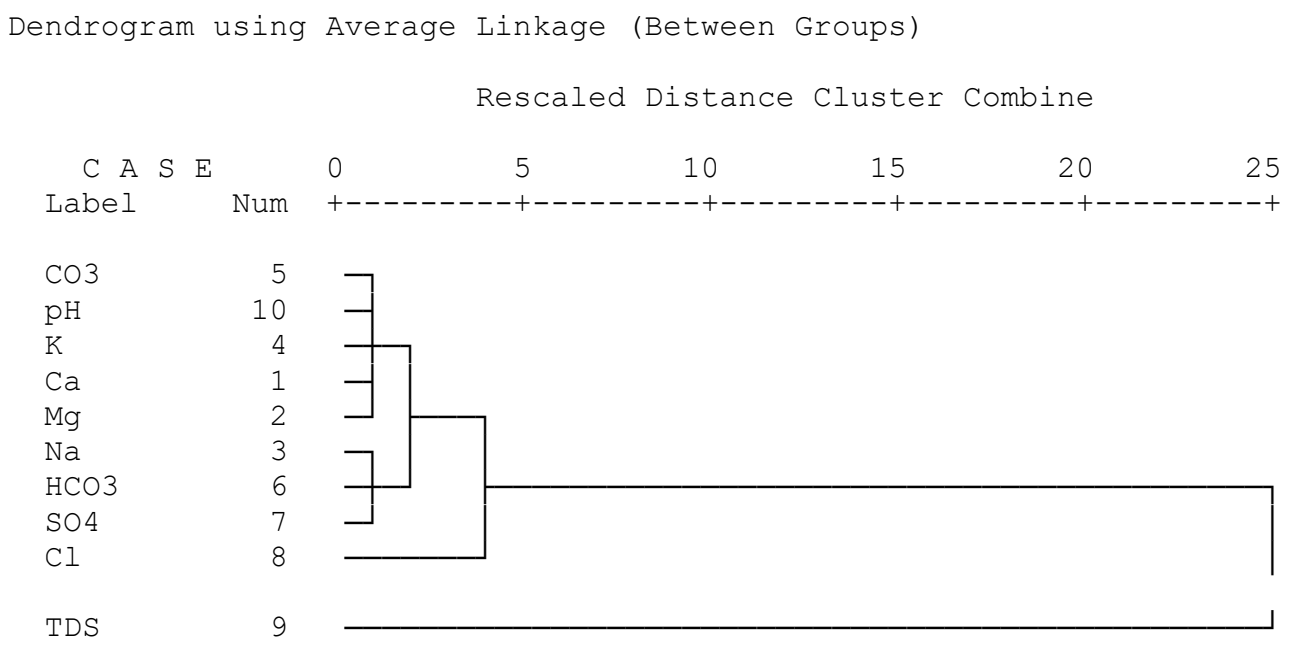

Fig. 7: Dendrogram (tree diagram) from cluster analysis for the Quaternary groundwater samples collected from NE El Fayoum area, Egypt

\subsection{Evaluation of water quality for irrigation based on Residual Sodium Carbonate (RSC)}

The term Residual Sodium Carbonate (RSC) is defined and calculated as follows:

$$
\mathrm{RSC}=\left(\mathrm{CO}_{3}{ }^{2-}+\mathrm{HCO}_{3}^{-}\right)-\left(\mathrm{Ca}^{2+}+\mathrm{Mg}^{2+}\right) \text { all expressed in epm/l. }
$$

This means that the RSC equals the sum of the bicarbonate and carbonate concentrations minus the sum of the calcium and magnesium ion concentrations. The residual sodium carbonate (RSC) equation is used to indicate the potential for calcium and magnesium precipitation at soil surface and removal of calcium and magnesium from the soil solution. As the RSC increases, much of calcium and some magnesium are precipitated from the solution when water is applied to soil, increasing the sodium concentration and the rate of sodium sorption on soil particles which increases the potential for sodium hazard. The (RSC) is used to distinguish between the different water classes for irrigation purposes because the high concentration of bicarbonate leads to an increase in the $\mathrm{pH}$ value, which causes the dissolution of the organic matter. Moreover, the high concentration of bicarbonate ions in the irrigation water leads to its toxicity and affects the mineral nutrition of plants.

The degree of sodium hazard based on RSC values is shown in Table (5). None, low and medium sodium hazard means the water is suitable for irrigation, while high hazard indicate that water is unsuitable for this purpose.

Table 5: Classification of irrigation water based on RSC values (College of Agricultural Sciences, 2002).

\begin{tabular}{ll}
\hline RSC value & Sodium Hazard \\
\hline$<\mathbf{0}$ & None. \\
$\mathbf{0 - 1 . 2 5}$ & Low, with some removal of calcium and magnesium from irrigation water. \\
$\mathbf{1 . 2 5 - 2 . 5 0}$ & Medium, with appreciable removal of calcium and magnesium from irrigation water. \\
$\mathbf{2}$ 2.50 & High, with most calcium and magnesium removed leaving sodium to accumulate. \\
\hline
\end{tabular}

Based on the RSC values (Table 6) calculated for surface and groundwater samples collected from the study area, all canals and drains are suitable for irrigation since they have negative values of RSC with none sodium hazard. Furthermore, the negative values of RSC indicate no problem of carbonate and bicarbonate content in the irrigation water. Most groundwater is suitable for irrigation with none or low sodium hazard. Only $17 \%$ of groundwater is unsuitable for irrigation due to the high sodium hazard (the RSC > 2.5). 
Table 6: Evaluation of water resources in northeast El Fayoum area for irrigation based on the RSC.

\begin{tabular}{|c|c|c|c|c|c|}
\hline Sample No & RSC & Hazard/ Evaluation & $\begin{array}{c}\text { Sample } \\
\text { No }\end{array}$ & RSC & Hazard /Evaluation \\
\hline \multicolumn{3}{|c|}{ Surface water (Canals) } & \multicolumn{3}{|c|}{ Quaternary groundwater } \\
\hline 2 & -5 & None / Suitable & 10 & -7.3 & None / Suitable \\
\hline 4 & -5.7 & None / Suitable & 11 & 5.8 & High / Unsuitable \\
\hline 8 & -0.5 & None / Suitable & 12 & -1.7 & None / Suitable \\
\hline 16 & -0.4 & None / Suitable & 13 & 1.1 & Low / Suitable \\
\hline \multicolumn{3}{|c|}{ drains } & 14 & 0.4 & Low / Suitable \\
\hline 1 & -11.5 & None / Suitable & 15 & -6.6 & None / Suitable \\
\hline 3 & -9.4 & None / Suitable & 17 & -3.5 & None / Suitable \\
\hline 6 & -2.1 & None / Suitable & 18 & 5.1 & High / Unsuitable \\
\hline 7 & -5.5 & None / Suitable & 19 & 1.1 & Low / Suitable \\
\hline 22 & -8.8 & None / Suitable & 20 & -1.9 & None / Suitable \\
\hline 29 & -5.5 & None / Suitable & 21 & 3.5 & High / Unsuitable \\
\hline \multicolumn{3}{|c|}{ Lake Qarun } & 23 & -16.1 & None / Suitable \\
\hline \multirow[t]{5}{*}{5} & -116.3 & None / Suitable & 24 & -27.9 & None / Suitable \\
\hline & & & 25 & 1.1 & Low / Suitable \\
\hline & & & 26 & -12.6 & None / Suitable \\
\hline & & & 27 & -2.3 & None / Suitable \\
\hline & & & 28 & 0.44 & Low / Suitable \\
\hline
\end{tabular}

\section{Conclusion}

The current study deals with the major ion chemistry of water resources in north-east El Fayoum depression area where the following can be concluded: (1) The salinity of canals water range from 256 to $299 \mathrm{ppm}$ indicating fresh water category, while some canals have brackish water category (1631$2099 \mathrm{ppm}$ ) because they may gain more salinity by leaching and dissolution of clay deposits. On turn, the salinity of drains water vary between 1370 to $4009 \mathrm{ppm}$ which indicate brackish water category because drains continuously receive soluble salts from land washing and drainage. The salinity of the Quaternary aquifer water ranges from $574 \mathrm{ppm}$ to $8953 \mathrm{ppm}$ indicating fresh to brackish water category with few saline samples. Furthermore, the salinity increases generally towards the Qarun Lake which has salinity of $48186 \mathrm{ppm}$ and is classified as hyper saline water due to the evapo-concentration process. The groundwater moves at the same direction of salinity increase. (2) The most dominant water type is Cl-Na which represented by $44 \%$ of groundwater samples and it characterizes the groundwater with the highest salinity in the study area. $28 \%$ of samples have $\mathrm{HCO}_{3}-\mathrm{Na}$ water type reflecting the meteoric origin of groundwater and $28 \%$ of samples have $\mathrm{SO}_{4}-\mathrm{Na}$ water type which may reveals dissolution of terrestrial salts. (3) The order of cationic dominance in the Quaternary groundwater at east El-Fayoum area are $\mathrm{Na}^{+}>\mathrm{Mg}^{2+}>\mathrm{Ca}^{2+}$ at $72 \%$ of total samples and $\mathrm{Na}^{+}>\mathrm{Ca}^{2+}>\mathrm{Mg}^{2+}$ at the rest of samples. In turn, the order of anions sequence are $\mathrm{Cl}^{-}>\mathrm{SO}_{4}{ }^{2-}>\mathrm{HCO}_{3}{ }^{-}(44 \%$ of total samples and advanced stage of metasomatism), $\mathrm{SO}_{4}{ }^{2-}>\mathrm{HCO}_{3}{ }^{-}\left(\mathrm{Cl}^{-}\right)>\mathrm{Cl}^{-}\left(\mathrm{HCO}_{3}{ }^{-}\right)(28 \%$ of samples $)$ and $\mathrm{HCO}_{3}>\mathrm{SO}_{4}{ }^{2-}\left(\mathrm{Cl}^{-}\right)>\mathrm{Cl}^{-}$ $\left(\mathrm{SO}_{4}{ }^{2-}\right)$ at $28 \%$ of samples (low stage of metasomatism). (4) There is no pollution with $\mathrm{Ag}, \mathrm{Cd}, \mathrm{Cr}, \mathrm{Mn}$, $\mathrm{Mo}, \mathrm{Ni}, \mathrm{Zn}$ because their concentrations are less than their maximum permissible limits. Most surface water systems and the Quaternary groundwater are polluted with iron since they have values of $\mathrm{Fe}$ concentration more than the maximum permissible limit of iron $(0.3 \mathrm{mg} / \mathrm{l})$. The waters of most canals are not polluted with lead $(\mathrm{Pb})$, while half of drains water and the water samples collected from Quaternary aquifer are polluted with lead. (5) The high surface reactivity of kaolinite clay has been used to separate copper (II) ions from groundwater samples, with removing value of $92 \%$ of the ions. (6) The intensive agricultural activities have clear effect on groundwater quality especially the application of fertilizers containing $\mathrm{P}$ and $\mathrm{N}$. The nitrate concentrations at surface water range between 0.61 and $10.497 \mathrm{mg} / \mathrm{l}$, while their concentrations at the groundwater range between 0.293 and $14.288 \mathrm{mg} / \mathrm{l}$. Industrial activities at the northern part of the study area have also bad effect on both surface and groundwater because most factories discharge their untreated or partially treated effluent directly to the sewerage network. (7) The multivariate statistical analyses (including correlation and cluster analyses) were used to identify the hydrogeochemical processes affecting groundwater composition. Based on this statistical investigation, these processes are sulfate dissolution, ion exchange and water-rock 
interactions. (8) Surface water and the majority of groundwater are suitable for irrigation based on the residual sodium carbonate (RSC) criteria.

\section{References}

Abdel Wahed, M.S.M., E.A. Mohamed, M.I. El-Sayed, A. M'nif, M. Sillanpa, 2014. Geochemical modeling of evaporation process in Lake Qarun. Egypt J. Afr. Earth Sci., 97:322-330.

Baioumy, H.M., H. Kayanne, R. Tada, 2010. Reconstruction of lakelevel and climate changes in Lake Qarun, Egypt, during the last 7000 years. J. Great Lakes Res., 36:318-327.

Beadnell, H.J.L., 1905. The Topography and Geology of the Fayum Province of Egypt. Survey Department of Egypt, Cairo, 101.

Chebotarev I., 1955. Metamorphism of Natural Waters in the Crust of Weathering. Geochimica et Cosmochimica Acta, 8: 137-170.

College of Agricultural Sciences, 2002. Irrigation water quality. The Pennsylvania State University, USA.

(http//www.cas.psu.edu/docs/casdept/turf/Education/Turgeon/Casestudy/OldRanch/IrrWatQual.h tml). 14.02.2002

EHCW, 2007. Egyptian Higher Committee for water Standards for drinking and domestic uses.

El Abd, E.S.A. and M.M. El Osta, 2014. Waterlogging in the New Reclaimed Areas Northeast El Fayoum, Western Desert, Egypt, Reasons and Solutions. Journal of Water Resource and Protection, 6, 1631-1645. http://dx.doi.org/10.4236/jwarp.2014.618147

El- Baroudy, A.A., 2013. Evaluating Environmental Sensitivity to Desertification in El-Fayoum Depression, Egypt. Egypt. J. Soil Sci., 53(3):445 - 460.

El-Sheikh, A.E., 2004. Water Budget Analysis of the Quaternary Deposits for the Assessment of the Water Logging Problem in El Fayoum Depression. Ph.D. Thesis, Faculty of Science, Al-Azhar University, Egypt, 356.

Hoffman, G.J. and D.S. Durnford, 2000. Drainage Design for Salinity Control. In: Skaggs, R.W. and van Schilfgaarde, J., Eds., Agricultural Drainage. Agronomy No.: 38. American Society of Agronomy, Madison, 579-614.

Kusky, T.M., M.A. Yahia, and T. Ramadan, 2001. Notes on the Structural and Neotectonic Evolution of El Fayoum Depression, Egypt: Relationships to Earthquake Hazards. Egyptian Journal of Remote Sensing and Space Sciences, 2: 1-12.

Kusky, T.M. and T. Ramadan, 2002. Structural Controls on Neo-Proterozoic Mineralization in the SE Desert, Egypt: An Integrated Field, Landsat TM, and SIR-C/X SAR Approach. Journal of African Earth Sciences, 35: 107-121. http://dx.doi.org/10.1016/S0899-5362(02)00029-5

Ongley, E.D., 1999. Water quality management: design, financing and sustainability considerations. In: In Proceedings of the African Water Resources Policy Conference, Nairobi, 26-28 May, the World Bank.

Said, R., 1962. The Geology of Egypt. Elsevier, Amsterdam.

Said, R., 1981. The Geological Evolution of the River Nile. Springer, Berlin.

Tamer, A.M., 1968. "Subsurface geology of the Fayoum region” M.Sc. Thesis, Fac. of Sci., Alex. Univ., Egypt.

Kusky, T.M., M.R. Talaat, M.H. Mahmoud, and G. Safwat, 2011. Structural and Tectonic Evolution of El-Faiyum Depression, North Western Desert, Egypt Based on Analysis of Landsat ETM+, and SRTM Data. Journal of Earth Science, 22: 75-100. http://dx.doi.org/10.1007/s12583-011-0159-8

WWAP, 2009. World Water Development Report 3 ' 'Water in a Changing World'. UNESCO, Paris, France.

Wang, S.W., C.W. Liu, and C.S. Jang, 2007. Factors responsible for high arsenic concentrations in two groundwater catchments in Taiwan. Applied Geochemistry, 22:460-476.

WHO, 2011. World Health Organization, Guidelines for drinking-water quality, fourth edition. 564p. ISBN: 9789241548151. 